\title{
Open spaces: windows for ecological urbanism in the Eastern Amazon'
}

\section{Espaços livres: janelas para um urbanismo ecológico na Amazônia oriental'}

Louise Barbalho Pontes ${ }^{[0]}$, Ana Cláudia Duarte Cardoso ${ }^{[0]}$

[a] Universidade Federal do Pará (UFPA), Belém, PA, Brazil

\begin{abstract}
The Brazilian Amazon has provoked preservationist discussions for decades, and although there has been a breakthrough in the recognition of the role of traditional populations for the biome maintenance, most strategies adopted in the country privileged the region's scale, without concern about local scale, particularly features of cities and of their inhabitants. The hypothesis that is pursued in this article is that the space of Western Amazonian frontier should offer innovative potential for urbanization solutions, especially in the treatment of open spaces. It also goes to prove that by not fully having structured its territory it could learn from human history, science framework, and from traditional knowledge. Assuming that urbanization process across this region takes place in a single space-time, this paper first approaches the dichotomy between city and nature built over time to deconstruct it, considering contemporary city's emerging spatiality and possible evolution scenarios. Marabá was adopted as case study, a city located between states and biomes, in the economic frontier circumstances of Western Amazonian. The research shows that from the existing open spaces raise an encouragement to reconcile urbanism and ecology.
\end{abstract}

Keywords: Amazonian cities. Amazonian frontier. Open spaces. Ecological urbanism.

\section{Resumo}

A Amazônia brasileira tem despertado há décadas discussões preservacionistas, e embora tenha havido um avanço no reconhecimento do papel das populações tradicionais para o bioma, as estratégias adotadas no país se detém na escala macro da região, sem incorporar as particularidades das cidades e seus habitantes. A hipótese que se persegue neste artigo é que o espaço de fronteira da Amazônia oriental ofereceria potencial de inovação para as soluções de urbanização, especialmente no tratamento dos espaços livres, e que por não ter seu território plenamente estruturado poderia aprender da história, do arcabouço da ciência e das soluções que

\footnotetext{
${ }^{1}$ Some ideas presented in this article were first developed in an article presented at the III APP URBANA Seminar, held in Belém, Brazil availabe at http://anpur.org.br/app-urbana-2014/anais/ARQUIVOS/GT1-105-121-2014031153723.pdf

LBP is Architect; Master in Architecture and Urbanism at Universidade Federal do Pará, e-mail: louise_bp@hotmail.com ACDC is Architect; MA in Urban Design (Universidade de Brasília, 1994); PhD in Architecture (Oxford Brookes University, 2002); Lecturer at Universidade Federal do Pará, e-mail: aclaudiacardoso@gmail.com
} 
emergem espontaneamente. Partindo da premissa de que o processo de urbanização dessas cidades se realiza em um espaço-tempo único procura-se, primeiramente, desconstruir a visão dicotômica de cidade e natureza construída ao longo do tempo e refletir a respeito das novas espacialidades da cidade contemporânea com intuito de refletir a respeito de caminhos possíveis. Adota-se como estudo de caso a cidade de Marabá, situada em fronteira de estados, de biomas e em situação de fronteira econômica em contexto amazônico. A pesquisa aponta que dos espaços livres existentes emerge um alento para reconciliar urbanismo e ecologia.

Palavras-chave: Cidades amazônicas. Fronteira amazônica. Espaços livres. Urbanismo ecológico.

\section{Introduction}

The wealth of the Amazon region is unquestionable, it has been treated as a mundi- frontier since its colonization; it is consistently mentioned in environmental debates worldwide. What has been less discussed is the fact that over $70 \%$ of its inhabitants lives in cities, where, until present day, has had no concern for environmental preservation, despite the central role that these urban centers might have on diffusion of ecological concepts and provision of better living conditions.

While preservationist procedures were reinforced at the regional scale, urban scale continues to be treated as free zone regarding environmental constraints only. In cities under economic frontier circumstances, development based on economic growth overrides inhabitants and their relationship with territory at great speed, resulting in serious environmental and social tensions, in loss of identity and belonging links. Despite pessimistic discussion, the hypothesis pursued in this article is that the Western Amazon frontier could offer innovative potential for urbanization solutions benefiting from ecological urbanism approaches, precisely as conversion of territory and society has not been completed yet. Thus, it is assumed that the urbanization process of these cities takes place in an unique space and time, having the greatest privilege of the opportunity to learn both from the framework of centuries of urban experiences in the world, as from the local traditional knowledge that has been able to match society and nature over centuries.

This article adopts the city of Marabá as a case study. Only a century old, the city attracted more than 300.000 inhabitants and a variety of urban experiences ranging from vernacular urbanization dependable on balanced exploitation of river and forest provisions, to a promise of modernist ideal city for the Amazon that mistook the complex frontier context. The sum of these experiences and the difficulty in dealing with the luxurious biome gave way to a discontinuous urban fabric intersected by open spaces.

Marabá was permeated by exchanges and diversity since its origins: the exchange between biomes, since it is located on the border between the savannas and the tropical forest; and exchange between cultures, for sheltering ribeirinhos, indigenous people, and migrants from all regions of the country.

Although the city has always been attractive, the discovery that it sits on one of the largest mineral provinces of the world has intensified its attractiveness and allure. The city's shape is extremely determined by physical site and impositions of the biome and rivers courses, as well as by successive economic cycles and by national development policies. The city is composed by six urban districts - Marabá Pioneira, Nova Marabá, Cidade Nova, Distrito Industrial, São Felix and Morada Nova (see Figure 1) - each district has a different origin and history, and also have different socio spatial arrangements expressing a peculiar sprawl process since each district is separated from the others by natural barriers (e.g.: flood plains, wide rivers).

Marabá has emerged as a trading post for extractive activities on a headland of land at the confluence of the rivers Tocantins and Itacaiúnas. This vernacular formation corresponds today to the Marabá Pioneira district, which housed the entire population of Marabá until 1970, when the city expansion begun (Raiol, 2010; Tourinho, 1991).

The urban fabric of Marabá Pioneira shapes a deformed grid that follows the edge of the rivers and sets place to a radial asymmetric structure that converges to the confluence of the rivers. Narrow streets and riverbanks compose most of the open spaces system. Streets with diversified land use and 

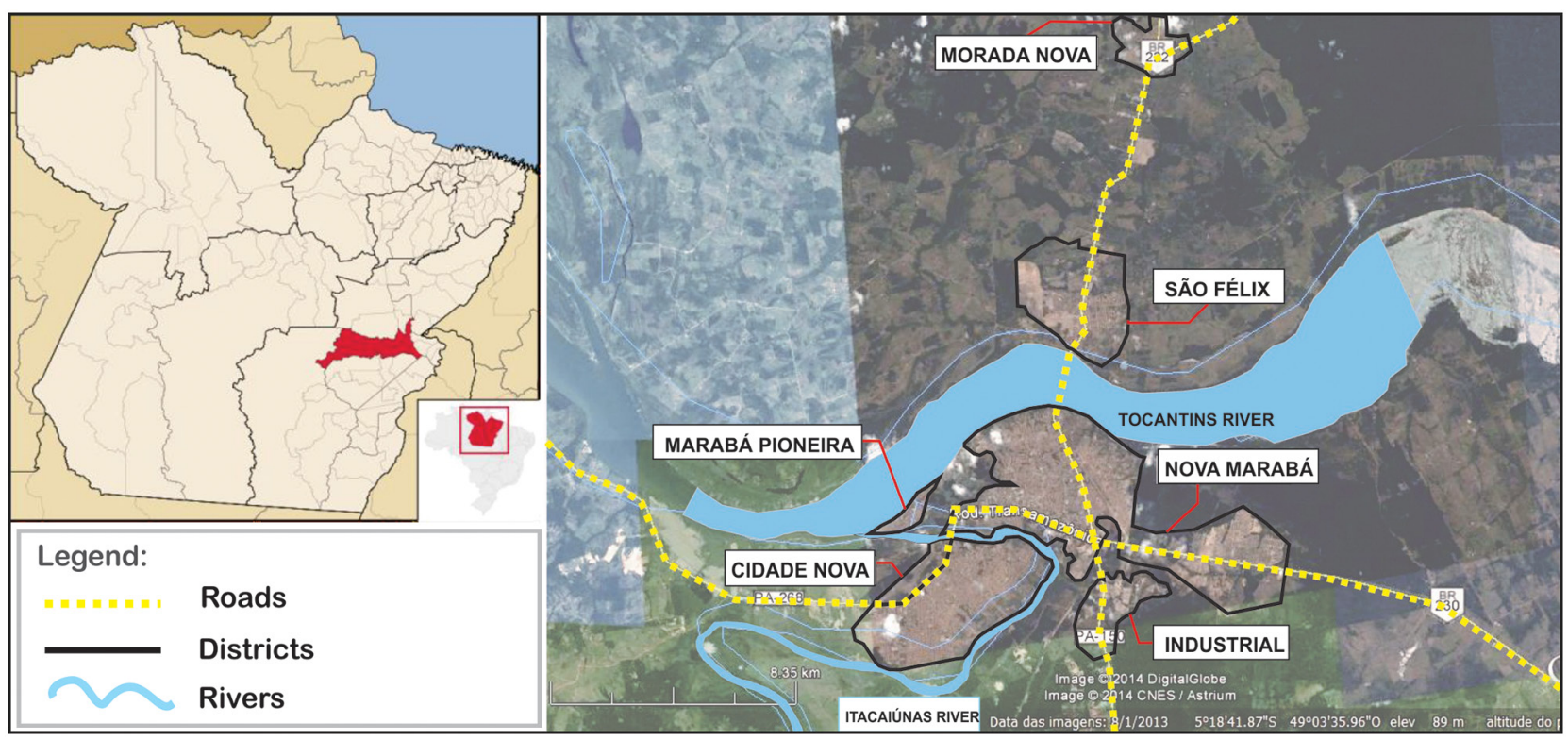

Figure 1 - Marabá's Localization and Urban Districts

riverbanks also are the main points of encounter, exchange and leisure. Previously to the Amazon's economic integration to the rest of the country, most houses had backyards from where it was possible to produce food and healing herbs. It was also prevailing the practice of building techniques adapted and resilient to rivers periodic (annual) flooding.

Since the 1970s, the discovery of astonishing mineral deposits repositioned those regions in a national and international work division as a natural resources supplier (of minerals, hydroelectricity, timber) through policies and fiscal incentives to land occupation by new productive uses. It opened an economic frontier to national and foreigner capital across south of Pará and other Brazilian states (Rondônia, Mato Grosso, Tocantins) where old inhabitants which were considered representative of backwardness by new comers, followed by a population growth of $72 \%$ between 1960s and 1970s. Marabá became a strategic city, crossed by highways, bridges and a railroad. The condition of new regional pole motivated the development of the Urban Expansion Plan of Marabá (Geddes, 1973), financed and executed by the Federal Government (in a rare intra-urban scale intervention): a modernist-inspired plan which promised to create an ideal city to Amazon, ensuring absorption of migration flows, sheltering of people affected by the seasonal floods and provision of a convivial atmosphere between inhabitants and forest. However, this idealization impinged upon the reality of the frontier condition and none of the promises have been fulfilled (Tourinho, 1991).

Ironically, years after the famous criticism of Alexander (1965) "the city is not a tree", the plan proposed a superblocks modulated space that evoked a chestnut tree leaves and branches: forming neighborhood units, surrounded by green areas connected by a hierarchical road system, "twigs" (streets) that should also comply with urban drainage function, justifying the amount of median strips and roundabouts of the formal area of this district. However, though the present plan exhibited advances regarding the topography use for drainage, water distribution or roads axis, they were not fully obeyed due to federal government withdrawal and local government incapacity to prevent informal occupation of non-implemented super blocks across 1980s economic crises. Like many planned cities in the region, the proposal lacked adherence on its deployment site (either physical or socio-cultural).

The plan presented very distinct features from Marabá Pioneira: low densities, activities decentralization, rivers and cars matrix digression that wiped out the streets as a place of coexistence. The Masterplan for Nova Marabá was concerned with "modernizing" (civilizing) the behavior of Marabá's inhabitants. This urban experimentation currently results in a hybrid of spatial structures planned and the endogenous spaces (informally produced) that reestablished the connection with the river. In these cases the streets were given new meanings, transforming the original 
plan to better suit the population aspirations and real needs. Despite the plan inadequacy, the interviews revealed that there is still a symbolic image of progress associated with that district.

On the opposite bank of Itacaiúnas river, another district was formed by amalgamation of disarticulated developments, and emerged as Cidade Nova district. This district emerged with a totally different design from the modernist district: an orthogonal but disconnected structure, with few open spaces. The district attracted large contingents of migrants, who could not afford the land in other districts, those who could not cope with floods of Marabá Pioneira, or could not adapt to urban innovations deployed in Nova Marabá.

In the North of the city, across the river, two districts were created: Morada Nova and São Félix, with a fragmented and poorly articulated urban fabric, with few open spaces, having the road that connects them to Nova Marabá as their only centrality and core.

Currently, the real estate market activity has further fragmented the city placing luxury gated communities and building lots at the Industrial District, and official housing programs (e.g.: Minha Casa, Minha Vida) in São Felix and Morada Nova; both strategies fostered quick conversion of rural land into urban land, raising a new trend to overcome natural barriers and of occupying previously reserved land, considered unsuitable for urbanization.

Despite the new trends, the consolidation of the six districts comprising Marabá created a discontinuous urban tissue, crisscrossed by open spaces that might represent an asset to equate city present problems (e.g.: precarious sanitation, shortage of public space).

Benefiting from findings on Marabá, the article highlights the potential of an ecological approach to the best understanding and conception of solutions on Western Amazonian cities fair with social and biological diversity, considering spatial morphology and topology in different scales, supported by qualitative research (interviews and social cartography). Although the region presents a clear trend towards a future of social exclusion and environmental degradation, empirical data shows that another path would be possible if a new paradigm was raised. The recognition that nature must have a space (e.g.: backyards, flood plains, river banks vegetation) would help the visibility in old social practices and in replace solutions that are usually considered under standard according to national metrics, but that are durable and valuable to Brazilian tropical forest preservation, if assumed that the city values contaminate its area of influence.

Thus, this article aims to highlight the importance of ecological urbanism for Amazonian cities, from both theoretical and empirical perspectives.

\section{Reation and dissolution of the city-nature dichotomy in the history of the city}

In order to understand the evolution of Amazonian cities, and the shift from river to road as their main structuring axis, and progressive homogenization of their landscape and culture, they must be framed in a context of crossed expectations that merges urban industrial rationality, permeated by worldviews socially created in the fully industrialized countries, with traditional productive system and living methods.

The region is perceived as periphery and there is a strong bias among well succeeded new comers and entrepreneurs attached to imported models, assumed as modern and universal, as well as more economically appealing than practices that cause less impact on natural site and social practices. The lack of research regarding local durable practices prevents innovation and fulfillment of local potential, and they are often destroyed before they are noticed or understood.

As urban studies are predominantly focused on metropolises and immersed in the urban-industrial city, often assumed as reference standard, the other multiple possibilities of relationship between society and environment are left out, thus overlooking the fact that the exogenous standard adopted were also socially constructed within another contexts. It is undeniable that the worldviews about city and nature adopted in Brazil were created at specific time points in history, and elsewhere to justify specific socioeconomic strategies. The cities' history shows that there was a long construction of the dichotomous view between city and nature (until the 1 st half of the 20th century) that just happened to be challenged in the last century (from the 2 nd half of the $20^{\text {th }}$ century).

Roots to Marabá's present circumstances are deeply laid in Western civilization values regarding how the relationship between nature and society should be.

In Europe, until the 14th century there was an inseparable relationship between society and nature and predominance of an organic worldview. It was only over the following centuries that private property 
overcame common goods (biological capital of the world) and entire ecosystems were devastated, and access to nature became a class privilege.

In a context marked by instability and insecurity in the medieval city, the walls, besides providing the craved security, separated what was city from what was nature in a dualistic and Manichaean view: inside the walls there were geometric and clearly controlled gardens associated to the idea of paradise (Eden) and outside there was "wild" uncontrolled nature associated with witches, where beasts and danger were found (Capel, 2002).

These ideas were not established at random: while the idea of dangerous and undesirable wild nature had the social function of legitimizing the exploitation of nature and degradation, the conception of a domesticated nature had the social function of selling a virtuous, sublime image, associated with exclusive class leisure. The notion of "human nature" historically served to justify the unjustifiable, the dissociation between society and nature (Smith, 1988).

In the Renaissance period, the idea that the man was the center of the universe reinforced such dichotomy, and paved the way for modern age, which that culminated with the abstract division between fields of knowledge and between city and nature as parallel universes (Herzog, 2013).

When urbanism emerged as a field of knowledge and of practice of a group of professionals, the field of gardening also strengthened up, both were primarily concerned with aesthetic dimension of space, but were able to create new spatial elements such as squares and plazas; the garden was a trial field that laid the foundation for additional ambitious urbanism projects to happen over the last two and half centuries (Capel, 2002).

In the industrial city, science evolution and popularity was useful to identify human health problems linked to the relationship between built space and nature: ventilation, afforestation or waterways when associated with the cleaning idea, appeared as elements of interest to urban planning. It was a utilitarian view of nature that presented it at service and under the control of planners. The creation of the first urban parks as city "lungs" or the rivers and streams channeling to ward off urban detritus belong to this period.

The focus of the capitalist-industrial system in the exploitation of natural resources was so well implemented that by the $19^{\text {th }}$ century there was a need to define natural spaces as not to be at risk of devastation. The first of them was Yellowstone Park in the United States (strategy that guided the Brazilian preservationist models). The creation of this kind of protective limits is extremely linked to the industrial rationality and to the belief that man is incapable of maintaining balanced relations with nature.

These concepts paved the way for the first urban operations that systematically dealt with open spaces. Following the example of interventions of Paris, by Haussman, or by Cerdá in Barcelona, that in spite of authoritarianism, influenced the production methods of cities around the world. More flexible experiences such as the Ringstrasse in Vienna (Cspelly-Knorr, 2011), the fringe belts identified by Conzen's studies (Whitehand, 2001) or the system of open spaces designed by Olmsted, may be highlighted as important urban experiences in the 19th century (Spirn, 1995).

The new spatial elements that emerged in the city contributed to the prestige of a low density urbanism with a stronger appeal to the symbolic rather than actual demands, the naive belief in science and technology as carriers of civilization, permeated the conception of ideal city that emerged in the first half of the 20th century, such as the Garden Cities proposed by Ebenezer Howard.

However, it was only after the World Wars and the perception of finiteness of natural resources and understanding of industrialized countries patterns of consumption that the view of nature has turned from useful to essential, paving the way for the environmental debate in vogue over the last few decades. Although it seems a distant history, the idea of nature (and its deriving spatialization) adopted nowadays is strongly related to the ideology of nature developed throughout this trajectory.

The colonization of Brazil took place under the ongoing dichotomous view of society and nature, sustained by dominating philosophies, advocated by science to justify exploitation and degradation in the colonies.

However, the colonizers strategy was not homogeneous for the whole Brazilian territory. While the country's coastline produced sugar cane and Atlantic Forest exploitation, Amazon was controlled and reserved for future exploitation and was treated as mundi-frontier being subject of dispute between Portuguese, Spanish, Dutch, British and French (Becker, 2013). It was kept 
in a different condition compared to the rest of the country to this very day; in the $18^{\text {th }}$ Century Portugal expected to subdivide Brazil and creating Brazil of North corresponding to present Amazon, as was the case of other Amazonian countries.

Human occupation was dispersed and scattered across the forest, dependent on river accessibility and possibility of extractive activities. Only two metropolises connected this vast region to the world, Belém and Manaus. Outside cities thrived with markets and places to access public services, with strong presence of public life at the river banks (place of ports, civic, retail and religious centrality), and easy connection with common areas (seen as either wild or rural) used to supply food, healing herbs, and provide leisure.

In the first half of the 20th century (when the Brazilian industrialization foundations were laid) there was an alignment of wealthier parts of Brazilian cities and European sanitary strategies when the hygienist view of nature was adopted. However, in the Amazon region (except for big cities such as Belem and Manaus) predominated the ribeirinho (traditional riverine people) way of living: extraction, family labor force and close relations between society and nature, way of life able to foster sustainability (Cardoso \& Ventura, 2013).

In Nothern countries, across the second half of the 20th century, there was an epistemological review that raised new fields of knowledge and a deep critique to the rationalist and authoritarian bases of current urbanism. Despite the long periods of time taken to align urban and environmental debates, approaches such as urban design and landscape urbanism, as well as urban experiences such as the Finger Plan in Copenhagen or the review of plans in Paris, Berlin or Barcelona post ECO-92 have indicated need for innovation based on identification of local potentials, social values and culturally built knowledge.

In the same period, Brazilian industrialization took the automotive industry as an anchor and prompted society to import spatial codes from the American suburban experience. Meanwhile, the modernist-inspired conception of space was embraced by the Federal Government, despite the existence of harsh criticism to those models in Nothern countries. In fact, while Europe lived an intense epistemological review, Brazil was ruled by a military regime and followed a developmentalist orientation, which prioritized economic rationality. The Brazilian Amazon was deeply transformed by military geopolitics, through economic integration and the exploitation of natural resources approach, that ended up turning up the region into an "urbanized forest" (Becker, 2013).

Reverberation of such epistemological review arrived in the 1980s, with the end of the military dictatorship, when social-based discussions were embraced, but the city's spatiality was relegated to a second plan. The approach to urban management adopted in the country (Master Plans) has had little influence over the city design or its relationship with biophysical dimensions. Only in the 21st Century, cities in Western Amazon started to organize cartography matching spatial and socio economic data that could deepen understanding of problems at local level, and their connections with invisibilities, such as of traditional inhabitants.

There is a profusion of concepts, proclamations, and promises to the city of the 21st century, and although such concepts are still under construction and few consensus were built, they highlight a need of conceiving other pathways based on the search for an ecological paradigm, in its deepest conception, including details of social relations and subjectivities, as well as about the environment where they are inserted.

While in Northern countries the maturation of urban studies has been based in the search for quality of life and diffusion of strategies such as SmartCodes, Green and Blue Grids or Systems of Open Spaces, Brazil still watches an intensification of urban and environmental problems, with reproduction of urban sprawl failed models.

Although the strategies developed in Northern countries do not reach the heart of global environmental problems, created by excessive consumption and unequal development, they may be used as an asset for global competition between cities, with undeniable benefits when, they reestablish the organic relationship between city and nature, and develop experiences and methods capable of transcending the industrial city dichotomous view and reconcile natural functions to human needs. This body of knowledge may better guide the search for urban-environmental quality around the world, such as Marabá, when migrants are proud of been pioneers in the fight against the forest Technological evolution and easy access to information and maps, made the contemporary frontier and the domination of "free lands" different 
from bygone frontiers. The present challenge is to avoid outdated misconceptions, and to seek paths that may lead to a gregarious city in its cultural, social and environmental dimensions, particularly in spaces that are not yet fully consolidated as in the case of the Amazonian frontier (see Box 1).

Present decisions might benefit from past lessons and capacity to acknowledge successful experiences; in addition to potential assets created by recent urbanization, mix of culture and of expectations about the possible urban experience in a region once dominated by tropical forest.

The contemporary city form: the new protagonist of open spaces

There are few studies on the city spatial features (natural and built) within Amazonian context, compared to other contemporary cities worldwide. Although authors studying the new spatiality of the contemporary city refer, in general, to the major global cities and metropolis, it is easy to see aspects of these spatialities unfolding in a city like Marabá.

The last century was not only the century of epistemological review, but also the century of worldwide urbanization and the comprehension that the city is the ultimate human habitat (Marshall, 2009). If before the big cities were concentrated in industrialized countries, today the great boom of urban growth is in the non-industrialized countries (Davis, 2006); the Amazon region is no exception to this pattern.

The more urbanized the world becomes, more knowledge about the city is gathered and paradoxically more difficult is its apprehension. Indeed, the evolution of technology and the speed of transport and communication have transformed the once compact and finite cities (easier to understand) in an open and sprawling reverse condition, hardly delimited, in a spatiality that is not finite, or controllable.

The old metaphor of the city as a machine or as an organism no longer fits in large urban areas. New forms and new descriptions emerged within the city (dual city, fractal city, generic city, infernal city or slums city), most of them reinforcing pessimism and clearly expressing the need of review in the ways the contemporary urban space is produced.

For Koolhaas's (2013) greatness and little theoretical depth on this topic have contributed to the poor quality of urban space. To the author's, greatness is independent of architects. Solà-Morales (2002) agrees with that view when he shows how much the urban fabric has become loose on the architects drawing boards, who are dedicated to specific points of the city, as if architecture were nothing more than containers, where everything can be controlled (climate, security, etc.) but that exempts respect or concern regarding what is around (the site and city itself).

The figure-ground reversal that took place in the transition from traditional to modern city, in the postmodern world, gave place to diffuse and polycentric spatiality, interspersed with "holes", "empty" open spaces, especially in those countries that have adopted the car oriented matrix, inspired by the American suburb spatial codes, like Brazil and show how much urban sprawl spreads and fades the boundaries between rural and urban.

Research reports recently conclude similar patterns in medium cities spatialities in the state of Para, Brazil (such as Marabá, Santarem and Altamira) (INPE, 2014). Although open spaces are all unbuilt spaces, public or private, not completely assimilated by the urban fabric or just empty or occupied by water and vegetation. They do not represent any urban or environmental quality assurance, since such spaces

Box 1 - Potential of the Amazonian frontier context

\begin{tabular}{l|l|l}
\multicolumn{1}{c|}{ DIFFERENT RATIONALITIES } & \multicolumn{1}{c|}{ PARTIALIY STRUCTURED SPACE } & \multicolumn{1}{c}{\begin{tabular}{c}
\multicolumn{1}{c}{ AVAILABILITY OF OPEN } \\
SPACES
\end{tabular}} \\
\hline $\begin{array}{l}\text { The economic context and late implementation of } \\
\text { logistics industry not fully homogenized spaces, and it } \\
\text { is still possible to find different forms of urban space } \\
\text { appropriation, old and new. }\end{array}$ & $\begin{array}{l}\text { It allows the privilege of learning from the centuries of } \\
\text { accumulated history and experiences in the world, gathering } \\
\text { a significant urban science framework, provided that there } \\
\text { is political will and capacity to create mediations between } \\
\text { situations of reference and local destinies. }\end{array}$ & $\begin{array}{l}\text { The imposition of the biome provided an urban fabric } \\
\text { intersected by open spaces not yet assimilated by } \\
\text { the market, by the urban-industrial logic or informally } \\
\text { occupied by population that cannot afford urbanized } \\
\text { land. }\end{array}$ \\
\hline
\end{tabular}

Original compilation from sources cited in the text.

urbe. Revista Brasileira de Gestão Urbana (Brazilian Journal of Urban Management), 2016 jan./abr., 8(1), 96-112 
may be degraded or may not represent any relationship with urban life, but they represent an important part of this new urban condition, and could become the backbone to the territory governance based on the continuity between city, wide and rural areas.

In the framework assembled by urban studies, three approaches can be highlighted to understand the open spaces as elements that can qualify the urban life and match city and nature: urban design, landscape urbanism and urban ecology.

\section{Available methodology: the framework assembled by science}

Urban design, landscape urbanism, urban ecology

Since the cited epistemological review, an important collection of experiences, theories and methodologies on the city materiality was gathered, however they had little influence on Brazilian urban policies.

Although there are no clear limits between the methods on how to study the city materiality, the approaches present even more convergence and become richer and richer in methodologies capable of revealing the place (loci) and it's potential.

If, on one hand, urban design relies more on the relationship between the built mass and the open spaces and on the support given to users (though divided into various categories and epistemological priorities), in another perspective the landscape urbanism seeks to understand beyond the elements of the city plan (routes, lots and buildings), the grid of biophysical relationships that support it, while the urban ecology focuses on the resilience of wildlife in urban areas (see Box 2).

Together, these approaches contribute to the construction of an ecological urbanism, in its deepest conception, that welcomes beside the environmental subject, social relationships and human subjectivity, through tools tested by several authors (e.g. apprehension methods and quality parameters) from several research lines that draw up the city's materiality universe of studies.

From this perspective, empirical analysis carried out in this paper aimed to unveil convergences between the three cited approaches, by adopting scales, layers and processes as tools to produce cartographies, which were complemented by interviews and field observation. The design principles presented in Box 3 were assumed as quality parameters for a comparative analysis of the studied districts of Marabá.

Beyond the universal: the importance of the context

However, in addition to universal methods, it is important to remember the importance of the contexts and the correspondence between the planner's expectations and the real demands.

A more impeller than normative positioning perspective is needed seeking to understand facts that state the ongoing processes and local particularities and to go beyond a romanticized idea or a mercantile

Box 2 - Comparative Matrix for Urban Design, Landscape Urbanism and Urban Ecology Approaches

\begin{tabular}{l|l|l|l}
\hline \multicolumn{1}{|c|}{ URBAN DESIGN } & \multicolumn{1}{|c|}{ LANDSCAPE URBANISM } & \multicolumn{1}{c}{ URBAN ECOLOGY } \\
\hline RESEARCH FOCUS & $\begin{array}{l}\text { Relations between built and open spaces design } \\
\text { and its impact in human life }\end{array}$ & $\begin{array}{l}\text { Relations between nature and human needs on } \\
\text { open spaces design and urbanism }\end{array}$ & $\begin{array}{l}\text { Relations between natural organisms, urban } \\
\text { structure and its surrounding }\end{array}$ \\
\hline KEY AUTHORS & $\begin{array}{l}\text { Alexander et al. (1977), Cullen (1978), Lynch } \\
\text { (1999), Gehl (2006) }\end{array}$ & Mcharg (1969), Spirn (1995), Hough (1995) & Dramstad et al. (1996) \\
\hline SCALE OF WORK & $\begin{array}{l}\text { City, District, Neighborhood, Streets, Plots, } \\
\text { Building, Furniture }\end{array}$ & $\begin{array}{l}\text { City, District, Neighborhood, Streets, Plots, } \\
\text { Gardens }\end{array}$ & Region, Territory, City \\
\hline DESIGN PRINCIPLES & $\begin{array}{l}\text { Design as a process, diversity, identity, security, } \\
\text { access, stativity, urbanity. }\end{array}$ & $\begin{array}{l}\text { Design as a process, diversity, identity, security, } \\
\text { access, stativity for people and for wild life }\end{array}$ & Connections, continuities, biological diversity \\
\hline ELEMENTS FOR SPATIAL & Plots, Routes and Buildings & Layers (water, earth, air, green areas, etc.) & Patches-Corridors-Matrix \\
ANALYSIS & Cartographies, field observations and interviews & overlapping layers & identifying remaining ecosystems \\
\hline ANALYSIS METHODS
\end{tabular}

Original compilation from sources cited in the text. 
vision of ecological urbanism. In fact a city planning for people to experience life in every way, contributing to the dissolution of the false barriers between city and nature or between rural and urban.

Thus, it is important to remember that to explore the urban frontier context is to "dive" into a mutant and hybrid reality, where temporalities and the ways of living and producing cities are mixed, and resist to the imposition of urban-industrial standards and its promises, that never reach the city as a whole.

\section{Open spaces in Marabá: windows for ecological urbanism}

At a glance, Marabá may seem a city that has few public spaces or urban quality for people, where ecological reconstruction and search for new paradigms might be distant. However, in a deeper analysis, it is possible to observe a huge presence of open spaces (as evidenced in the cartography), and the use of areas not strictly urbanized for leisure in the city (evidenced by interviews and field observations).
Evidences show that environmental concern does not reach the city (local) scale, where most of the population lives in Western Amazon. To understand processes in course and envision possible proposals for an ecological urbanism, the space of Marabá was decomposed in three scales (territorial scale, urban scale and district scale) and each scale was subdivided in layers (water, roads/railroads, topography and vegetation), and as the scale decreased further analysis elements became visible (see Figure 2). In the territorial scale is important to highlight the importance of the Amazon forest for the country and the world, and show that Marabá is in the area called Arc of deforestation reinforcing the importance of environmental strategies at that place. In Marabá surroundings we can find dense forests, open forests and disturbed areas. The county is predominantly rural and most of the territory is occupied by farms, the urban area occupies only a small portion at the north of the whole municipality. The layers crossing reveals how intertwined the preserved areas and waterways are, and, in that sense the large number of rivers in the region contributes to the biome preservation

Box 3 - Guidelines for open spaces analysis in Marabá

\begin{tabular}{c|c}
\hline \multicolumn{2}{c}{ Guidelines for open spaces analysis in Marabá } \\
\hline ELEMENTS FOR SPATIAL ANALYSIS & SCALES, LAYERS AND PROCESSES \\
\hline QUALITY PARAMETERS & DIVERSITY, ATTRACTIVELY, COMFORT, ACCESS, SECURTY AND IDENITIY \\
\hline ANALYIS METHODS & CARTOGRAPHIES, FIELD OBSERVATIONS AND INTERVIIEWS \\
\hline
\end{tabular}

Original compilation from sources cited in the text.

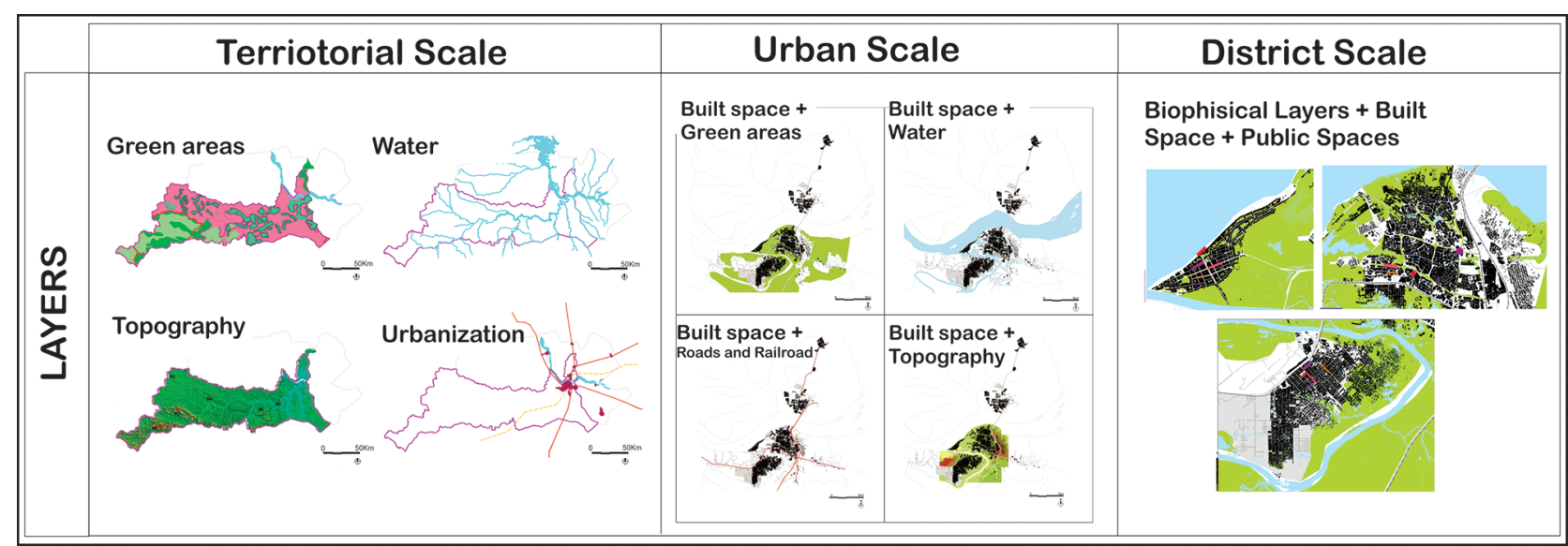

Figure 2 - Scales and Layers: Steps of Analysis Applied to Marabá Authors (2014). Cartographic base: IRS-R2-LISS3 (INPE, 2010). 
(three river basins cut the county and three are fully contained in its territory).

The urbanized area corresponding to the city of Marabá has a polynuclear and ragged shape by open spaces, particularly rivers and wetlands; it has four axes of expansion corresponding to the highways that cross the city. In addition to the open spaces not designed for appropriation by people. Over the six districts comprised it was identified by eight squares and the urbanized riverbank of Tocantins River, which are quite attractive to the population. The crossing of the layers in the urban scale unveils the links between water and preserved areas, and also the relationship between topography with more or less informal areas (the occupation of the lower levels is usually associated with informal use).

For the analysis of the district scale were adopted only the three biggest districts, since they basically concentrate all the city's services and infrastructure. This scale of analysis allows the easier identification of biophysical and spatial layers and of qualitative criteria supported by literature and the testimonies of the interviewers.

The case of Marabá becomes even more interesting if analyzed as an urban trials laboratory, the three main districts were produced mainly by different actors: Marabá Pioneira had vernacular formation, Nova Marabá was planned by the State and Cidade Nova was formed by market strategies, each with its peculiarities, trends and unique designs, but all interwoven by a wave of informality and spontaneous interventions that invite us to reflect on the formal ways of designing city (see Box 4).

Thus it could be important to devote a closer look to the informally produced space, often associated with poverty and precariousness, since more than simple materials and improvisation, the endogenous formulations are loaded with innovations and ways (not yet discovered by the formal planning) to reconcile urban design and ecology, space built and

Box 4 - Comparative Analysis and Lessons from Marabá's Districts

\begin{tabular}{|c|c|c|}
\hline Quality Parameters & \multicolumn{2}{|c|}{ District Performance } \\
\hline DIVERSITY & \multirow{6}{*}{\multicolumn{2}{|c|}{ MARABÁ PIONEIRA > CIDADE NOVA > NOVA MARABÁ }} \\
\hline ATTRACTIVELY & & \\
\hline COMFORT & & \\
\hline ACCESS & & \\
\hline SECURITY & & \\
\hline IDENTITY & & \\
\hline MAPARÁ PIONFIPA & YOYA MADÁ & CIRARE MOY \\
\hline MARABA PIONEIRA & NOVA MARABA & CIDADE NOVA \\
\hline $\begin{array}{l}\text { Use diversity, coexistence of different social classes, human scale, } \\
\text { pedestrianisation, respect for traditions and everyday life. No imposition of } \\
\text { an ideal way. Understanding of the importance of history to the creation of } \\
\text { identity (as a link that causes people to feel belonging to that place and feel } \\
\text { the need/necessity to take care of it); Afforestation and climate amenities, } \\
\text { preservation of traditional interactions with the river and the neighborhood. }\end{array}$ & $\begin{array}{l}\text { There is no ideal way and not an ideal } \\
\text { modern-man behaves as planned in a plan. } \\
\text { The overvaluation of the car causes the } \\
\text { death of living on the streets, empty the } \\
\text { street cause insecurity, the dryness doesn't } \\
\text { invite the coexistence, the low readability } \\
\text { of space invites you to stroll. The presence } \\
\text { of green areas contributes to the urban } \\
\text { drainage (these can be designed in a more } \\
\text { attractive and complete). The progress is } \\
\text { not even in the forms or in the materials } \\
\text { used but in improving the quality of life in } \\
\text { the city. }\end{array}$ & $\begin{array}{l}\text { Reconciling traditional relations and contemporary } \\
\text { structures. Ensure diversity of use of public space that } \\
\text { allows access to different income ranges. Need for } \\
\text { vegetation to absorb the impact of highways. Need } \\
\text { for soothing climate vegetation on the streets so that } \\
\text { invite the movement of pedestrians. }\end{array}$ \\
\hline
\end{tabular}

Original compilation from sources cited in the text.

Authors (2015). Cartographic base: Wikimapia (2015). 
nature, diversity, and equal access, categories highly recommended by postmodern literature.

Moreover, the informal space has been an alternative for those covered by the urban-industrial logic, a space of resistance and resilience of other rationalities and ways of interact with people and environment (as we can see in the cultivated backyards, in the knowledge about the forest, or in the capacity to live without tearing down the forest or in the leisure that does not degrade) (see Figure 3).

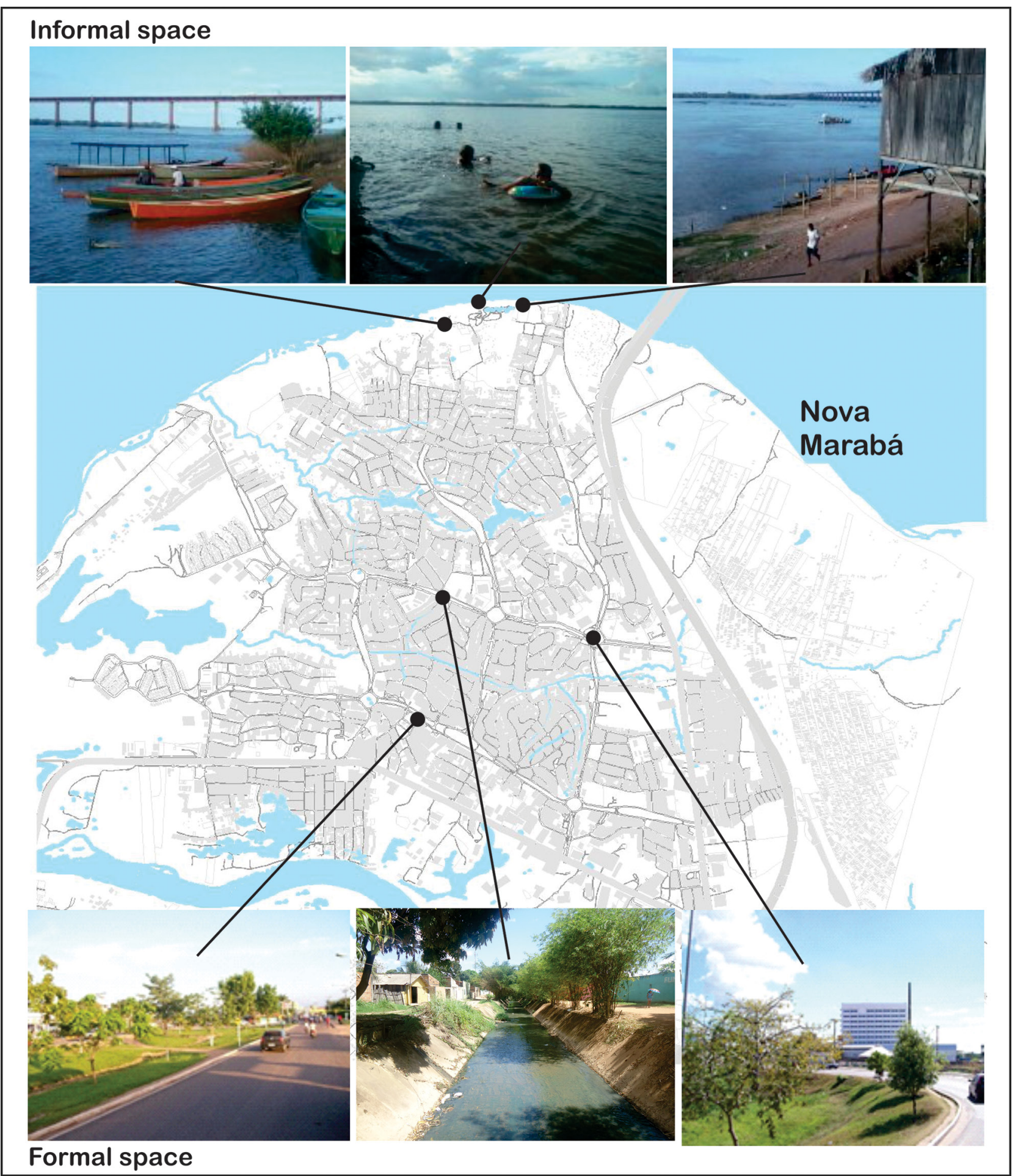

Figure 3 - Informal and formal space in Nova Marabá

Hybrid condition in Nova Marabá. Authors (2014). 
Interviews have showed many descriptions about leisure that go beside the squares and include rivers, the waterfall, the beach, trips to farms or nearby islands as key elements to inhabitants experience leisure, recreation and welfare. This evidences that leisure, interaction, identity and collective memory are extremely intertwined with the city's nature. The inseparable relationship between culture, city and nature is evident in Marabá, but is not part of the public management vision about public spaces production whose positions are occupied by new comers. The proximity and links between leisure, culture and nature gradually dissipate in desire for modernity that shapes in the city an exogenous model, which separates city and nature with all socio-spatial implications that this separation entails.

The intersection of the scales and layers were revealed three loss processes and a possible way to reverse it.

\section{The narrative of loss}

The fading of the backyards, is occurred ongoing fact in most big and medium size cities in Brazil due to the new dynamics of the housing market and the demand for built space in the cities, but that it is rarely mentioned as an environmental loss (given the biophysical role that they can meet the absorption of pollutants, rainwater, etc.) and in the Amazon region it is also a cultural loss, since gardens have been widely used for the production of food and medicinal products typical of the riverine culture, knowledge related to biome abundance that gradually cease to exist in the cities.

The fading of public spaces: despite the public spaces of Marabá still being very attractive, they have not been a priority for city managers; the greatest concern is settled in the progress ideology that associates development of major projects (works) involving large capital, but also environmental degradation, which has a strong impact on popular leisure alternatives and quality of life of Marabá. Works on Itacaiúnas and Tocantins Rivers, such as the forthcoming hydroelectric of Marabá, approved by the federal government, besides to attracting large numbers of workers (without any preparation to receive them) will destroy the only beach and the only waterfall available to city inhabitants, popular public spaces, full of historical and sentimental value for the population. It raises a new kind of exclusion, as the access to nature progressively becomes a high economic class privilege.

The fading of conservation areas: the established dichotomy on environmental preservation in Brazil has contributed a mismatch, while conservation areas are invisible to people, they disappear without public notice or awareness; and in this sense, urbanity may and should be a preservation strategy.

Marabá presents a scenario of diversity destruction of the ways of seeing and living the world, by homogenizing urban-industrial rationality, reaching all the territory scales. At the macro-scale, the great works and great environmental impacts are observed, and in the micro-scale backyards, private open spaces friendly to traditional knowledge and helpful in providing food security, are fading quickly due to the imported urban logics over recent decades.

The landscape design: how to reverse the loss

If so many people have lost their backyards, then public spaces and the interaction with nature are losing power, despite the fact that there are still people who are very connected to nature in the city, the open spaces appear with a boost not just to bring connection between the districts, but also to the reestablishment and recognition of the relationship between culture and nature. A system of open spaces and the landscape design can mean empowerment, innovation based on the actual demands and collective construction, in addition to providing environmental and urban quality.

To make the system of open spaces of Marabá visible, fragments ${ }^{1}$ and corridors have been identified (alongside the potential to create or complete them) in the grid they could form (matrix), as well as the articulation between the thicker and thin grain proposed by Richard T. T. Forman (Mostafavi \& Doherty, 2014) in the three scales (see Figure 4).

The produced images show that the system of open spaces of Marabá is fragmented and has not

\footnotetext{
${ }^{1}$ Enric Batlle explains Forman's concepts as: Patches como espacios de interés natural existentes o posibles. Corridors son elementos que permiten conectividad ecológica. Matrix como la malla o estructura ecológica que explica la forma y el funcionamiento de un mosaico (Batlle, 2011, p. 162-163).
} 


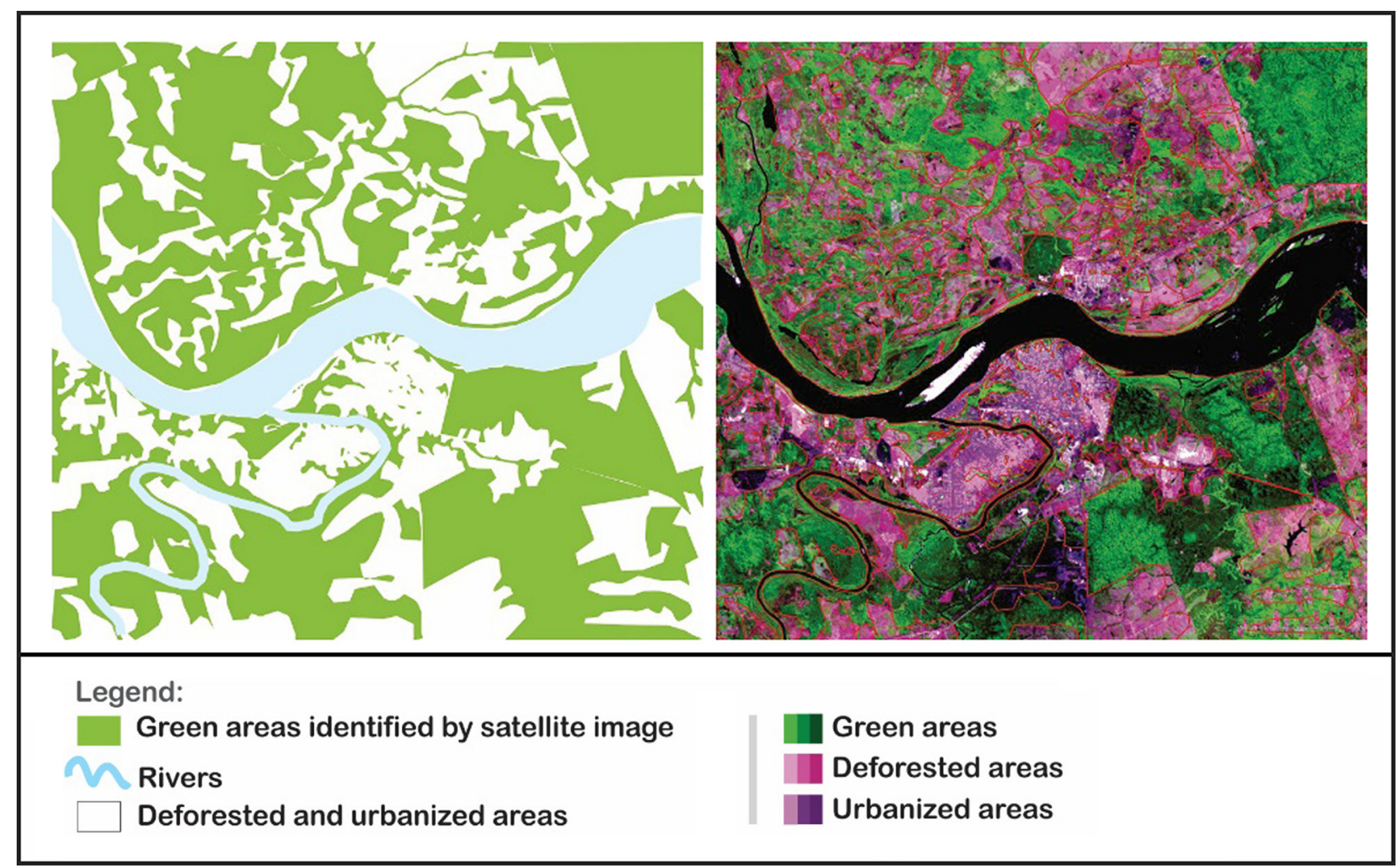

Figure 4 - Patches, corridors and matrix identified from satellite image

Authors (2014). Cartographic base: IRS-R2-LISS3 (INPE, 2010).

only been untreated in fact as a system, but also that the fragments could be easily articulated if the this intention was real.

On the territorial scale, we can see rural properties with small and large green covered fragments that correspond to areas of environmental preservation, but practically no corridors. However, the strong presence of rivers and their tracks of domain (referred as permanent preservation areas by environmental legislation in Brazil), in addition to the railroad, could easily act as potential corridors of wildlife able to connect scales and fragments (see Figure 5).

On urban scale, the remaining fragments of water imposition over the territory form practically green belts between the districts. Almost without any planning of open spaces, it occurs in a proportion indicated by the urban ecology, the entanglement between areas of thin grain (more densely populated and with small green areas within easy reach) with thicker grain areas (more distant and with large areas which allow the occurrence of greater diversity) that together provide the best setting for urban life and reproduction of wildlife (see Figure 6).
The district scale also has great potential for the creation of continuities.

In Marabá Pioneira, the most attractive, comfortable and accessible district which has genuine identity ties, has public spaces that may be designed in a systemic way with other open spaces, such as streets. The radial form of the streets ends in an area of environmental preservation and offers great potential for the formation of corridors through construction sites (already existing in the main avenues) and in residential areas of less traffic presents potential for planned streets in accordance with environmental parameters (permeable floors, afforestation, etc.) and social (speed reduction from cars, shared spaces, spaces for sitting, cycling, etc.) the woonerf defended by authors like Spirn (1995), Hough (1995) or Gehl (2013).

In Nova Marabá District, public spaces are poorer, less attractive and should be considered in order to become more attractive and comfortable. Furniture and vegetation should be provided to mitigate the climate and long distances. However, the drainage system through continuous and extensive beds and main strips also offers great possibilities of articulation 


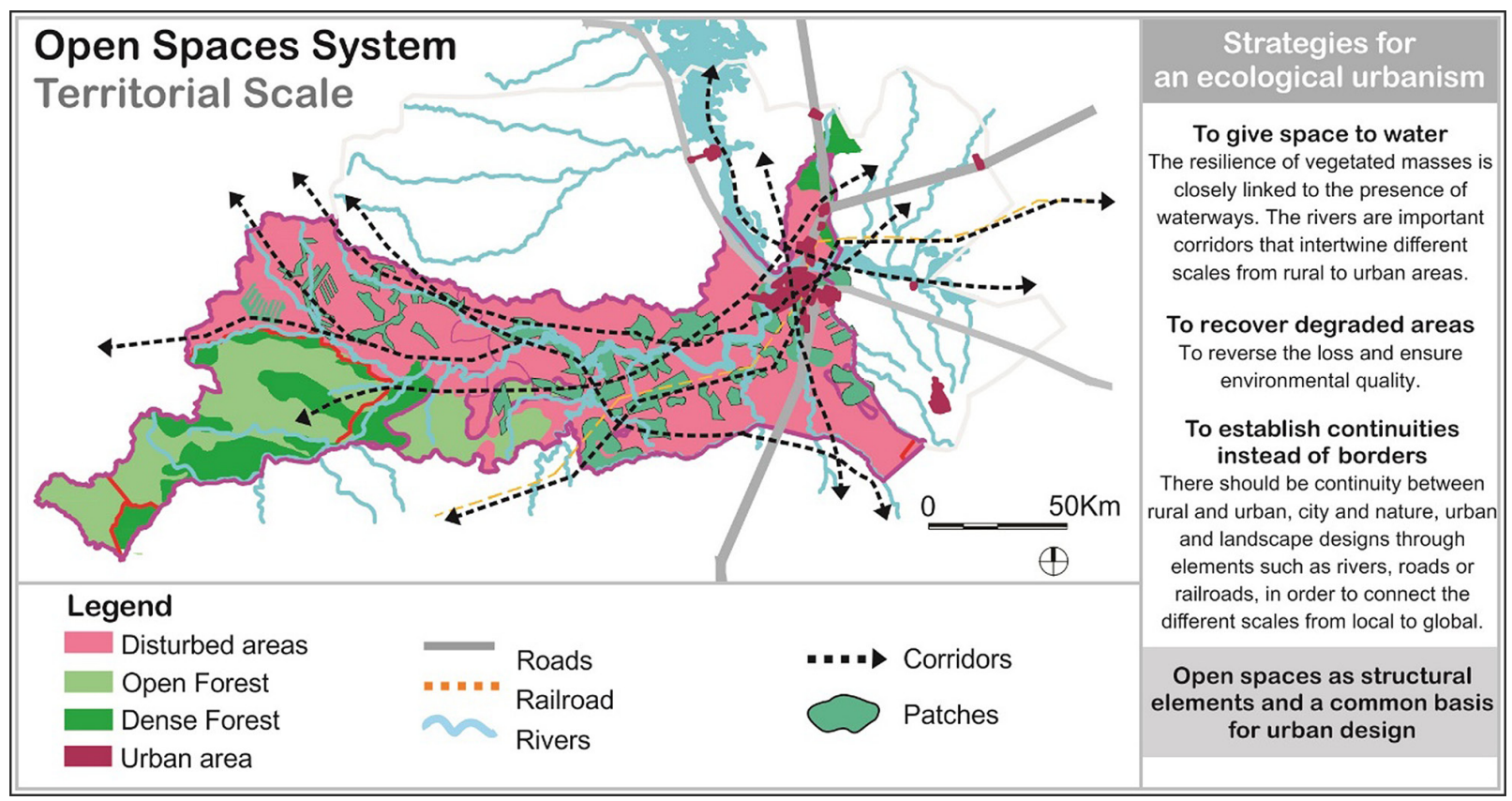

Figure 5 - Open Spaces System - Territorial Scale

Authors (2014). Cartographic base: IRS-R2-LISS3 (INPE, 2010).

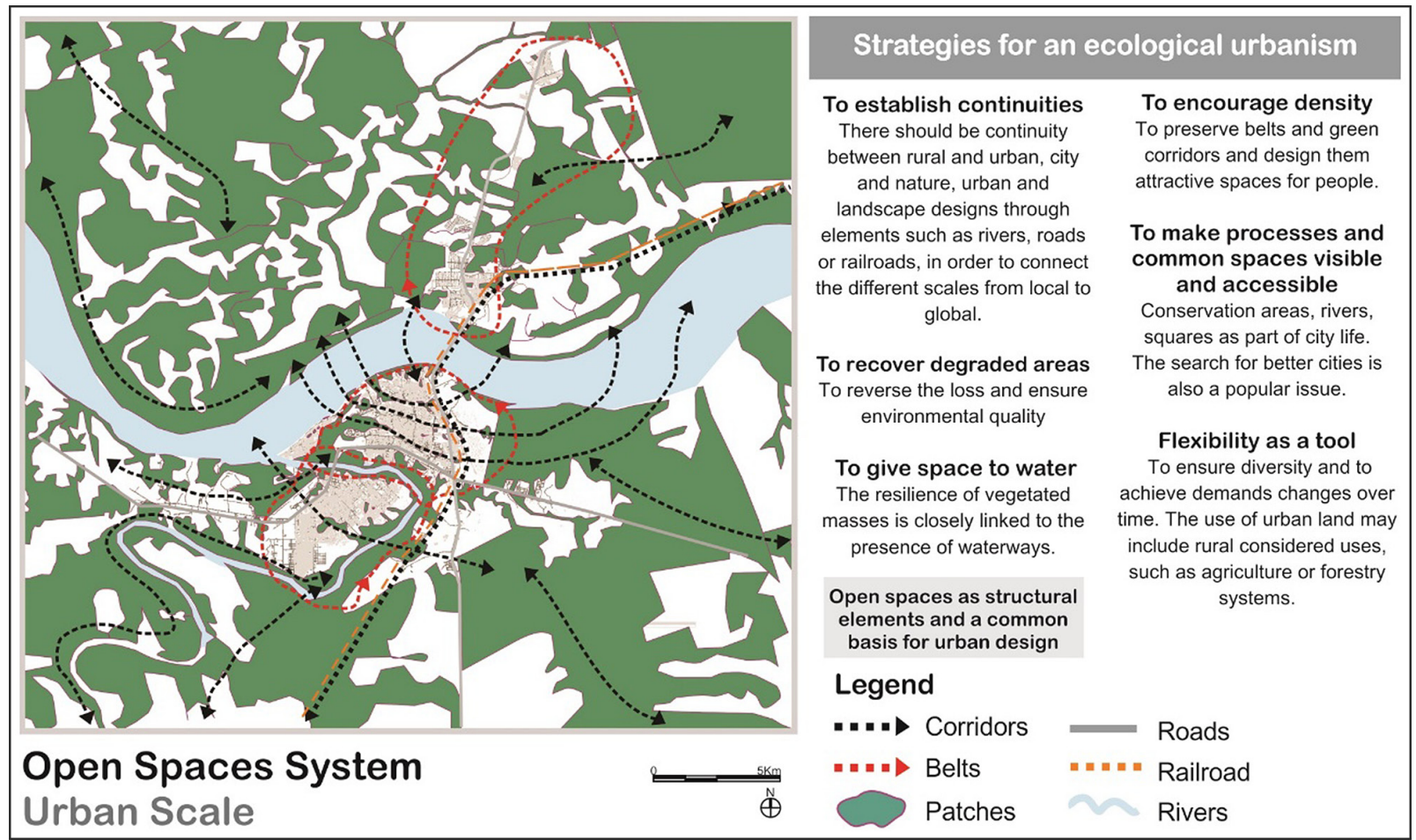

Figure 6 - Open Spaces System - Urban Scale

Authors (2014). Cartographic base:IRS-R2-LISS3 (INPE, 2010).

between the thicker grain areas and the interior of the district. Particular corridors can also minimize the impact of automobiles and create inviting spaces to stay, one of the major shortcomings of this space.
In Cidade Nova District, the orthogonal urban fabric is also connected to the preservation area and the streets could be designed in such a way as to create wooded corridors. The balnearies (places infrastructure 


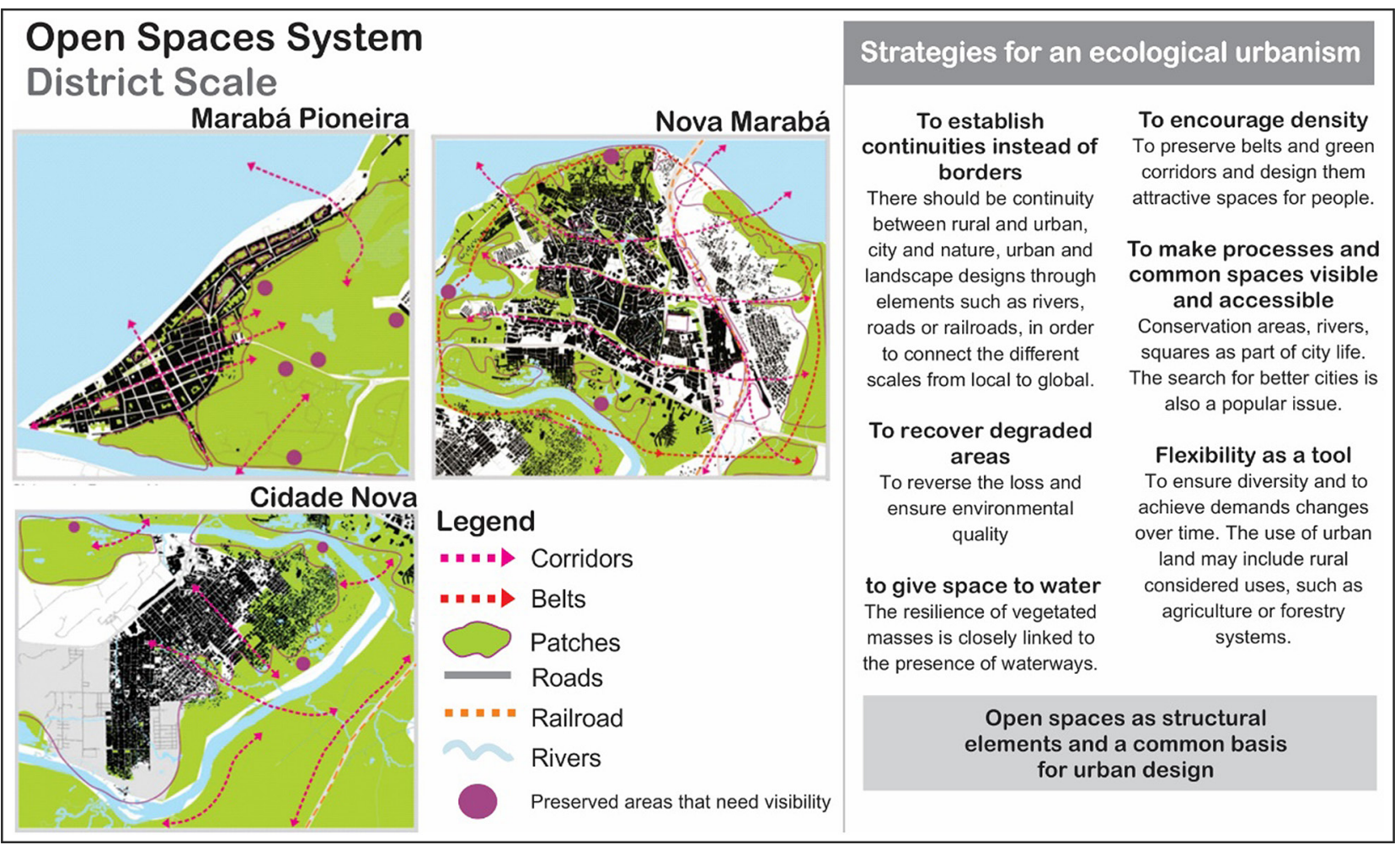

Figure 7 - Open Spaces System - District Scale

Authors (2014). Cartographic base: IRS-R2-LISS3 (INPE, 2010).

to support popular leisure on riverbanks) show the possibility coexistence of preservation and human activity, the human presence is not necessarily a risk and can be supportive to preservation (see Figure 7).

Linear parks can be encouraged on the banks of inner city rivers, squares and spaces for children and adults should be thought about in areas inside the nucleus, while the banks of the roads green spaces can be designed to minimize the traffic intensity of the impacts of cars and trucks.

From spaces transformed spontaneously, lesson of reconnecting inhabitants and rivers are taken, fostering diversity and simplicity. It is not a matter of financial resources by of understanding spatial patterns and potentials.

In addition, innovative experiences as orchards or urban gardens in partnership with universities or neighborhood associations can be thought to the flooded areas and lookouts could be created in the areas of preserved forest, encouraging preservation of popular knowledge about the biome, something crucial to reverse the process loss.

It is recommendable that design of open spaces is devised as a system, as basis for a joint city project, able to recognize potentials, and to foster utopias able to guide improvement projects for the city.

All of the presented evidence shows that Marabá has a great potential to reconcile urban and biophysical processes, the lack of planning and the economic rationality megalomania could not yet fully erase the diversity and environmental quality, despite the voracity in which this can occur.

\section{Final considerations}

The process of urbanization in an economic frontier conditions, in the Brazilian Amazon, takes place in a single space-time that has as its main privilege the opportunity to learn from both the framework assembled by science and from the endogenous experiences.

In the city of Marabá the biome imposition gave rise to discontinuous urban fabric, interspersed with open spaces. The availability of open spaces over the whole city territory is a differential that could be used to meet urban, environmental and cultural functions. However, the city's expansion process based on a 
vision of industrial progress is leading toward the disappearance of these spaces, as well as the culture that entwines ways of life and nature. It devaluates traditional people and the original forest.

Unlike most consolidated cities and metropolises taken as urban development references in Brazil, the shape and arrangement of existing open spaces in Marabá, although not treated as a system, could easily form corridors and an array of fundamental interest for the formation of a more gregarious city.

If design in Marabá were oriented by ecological urbanism, ties between culture and nature would be strengthened, to the benefit of urban and environmental quality. In addition it would assume actual continuity between rural and urban territories better connecting cities to tropical forest, and also new comers and local people, in the most urbanized part of Brazilian Amazon. It could be inspiring to other countries in South America and in Africa, where quite similar urbanization processes are in progress (e.g.: Mozambique).

To the narrative of loss, it is possible to respond with the landscape design, crossing the threshold of criticism to show that there are other possible and feasible paths. The design is then presented as an instrument for recognition and production of knowledge, and also as a tool to make scientifically visible the potential not easily recognized. Thus it would be possible to foster awareness about the fact that a periphery is only periphery while it cannot use its potential and wealth properly, due to lack of institutional support, misguided investment orientation, or imposition of outdated models and formulas. In addition, the emergence of a new paradigm of ecological urbanism, gestated by long experience in industrialized countries, could inspire new people and nature friendly processes and create more gregarious and happy cities to live in Western Amazon.

\section{Acknowledgements}

Authors acknowledge the support of CNPq, CAPES and UrbisAmazonia Research Project (Funcate, ITV, Fundação Vale).

\section{References}

Alexander, C. (1965). A city is not a tree (Architectural Forum, No. 122, p. 58-62). New York: Time Inc.

Alexander, C., Ishikawa, S., \& Silverstein, M. (1977). A pattern language. New York: Oxford University Press.

Batlle, E. (2011). El jardín de la metrópoli: del paisaje romántico al espacio libre para una ciudad sostenible. Barcelona: Gustavo Gili.

Becker, B. (2013). A urbe amazônida. Rio de Janeiro: Garamond.

Capel, H. (2002). La morfología de las ciudades. Barcelona: Ed. del Serbal.

Cardoso, A. C., \& Ventura, R., No. (2013). A evolução urbana de Belém: trajetória de ambiguidades e conflitos sócioambientais. Cadernos Metrópole, 1, 55-76.

Cspelly-Knorr, L. (2011). The birth of the theory of urban green systems in Britain and Hungary. Agriculture and Environment, 1, 41-53.

Cullen, G. (1978). El paisaje urbano: tratado de estética urbanística. Barcelona: Blume.

Davis, M. (2006). Planeta favela. São Paulo: Boitempo.

Dramstad, W., Olson, J., \& Forman, R. (1996). Landscape ecology principles in landscape architecture and land use planning. Washington: Island Press Harvard University.

Geddes, J. (1973). Plano de desenvolvimento urbano de Marabá. Marabá.

Gehl, J. (2006). La humanización del espacio urbano: la vida social entre los edificios. Barcelona: Reverté.

Gehl, J. (2013) Cidades para pessoas (Tradução Anita di Marco, 2nd ed.). São Paulo: Perspetiva.

Herzog, C. (2013). Cidade para todos: (re)aprendendo a conviver com a natureza. Rio de Janeiro: Inverde, 2013.

Hough, M. (1995). Cities and natural process. London: Routledge.

Instituto Nacional de Pesquisas Espaciais - INPE. (2010). IRS-R2. LISS 3. Índia: SDSC-SHAR. Imagem de satélite. Resolução 24m. UTM WGS 84. Retrieved in 15 June 2015, from http://www.dgi.inpe.br/CDSR

Instituto Nacional de Pesquisas Espaciais - INPE. (2014). Projeto UrbisAmazônia: relatório de pesquisa. São José dos 
Campos. Retrieved in 10 March 2015, from http://www. dpi.inpe.br/urbisamazonia/

Koolhaas, R. (2013). Três textos sobre a cidade. Barcelona, Gustavo Gili.

Lynch, K. (1999). A boa forma da cidade. Lisboa: Edições 70.

Marshall, S. (2009). Cities, design \& evolution. London: Routledge.

McHarg, I. L. (1969). Design with nature. New York: American Museum of Natural History.

Mostafavi, M., \& Doherty, G. (2014). Urbanismo ecológico. Barcelona: Gustavo Gili.

Raiol, J. A. (2010). Perspectivas para o meio ambiente urbano: GEO Marabá. Panamá: PNUMA. Retrieved in 23 May 2014, from www.pnuma.org

Smith, N. (1988). Desenvolvimento desigual. Rio de Janeiro: Bertrand Brasil.
Solà-Morales, I. (2002). Territórios. Barcelona: Gustavo Gili. Spirn, A. W. (1995). O jardim de granito. São Paulo: EDUSP. Tourinho, H. L. Z. (1991). Planejamento urbano em área de fronteira econômica: o caso de Marabá (Dissertation). Núcleo de Altos Estudos Amazônicos, Universidade Federal do Pará, Belém.

Whitehand, J. W. R. (2001). British urban morphology: the Conzenian tradition. Urban Morphology, 5(2), 103-109. Retrieved in 23 May 2014, from http://www.urbanform. org/pdf/whitehand2001.pdf

Wikimapia. (2015). Imagem de satélite. Retrieved in 15 June 2015, from http://wikimapia.org/\#lang=pt\&lat=$5.289939 \&$ lon $=49.097900 \& \mathrm{z}=11 \& \mathrm{~m}=\mathrm{b} \&$ show $=/ 4269598 /$ pt/Marabá\&search=Marab\%C3\%A1

Received: June 15, 2015

Approved: Oct. 08, 2015 


\section{Errata}

In the article "Open spaces: windows for ecological urbanism in the Western Amazon", DOI number: 10.1590/2175-3369.008.001.SE06, published in urbe - Brazilian Journal of Urban Management, 8(1): 96-112, on page 96:

Where it reads:

"Open spaces: windows for ecological urbanism in the Western Amazon"

It should read:

"Open spaces: windows for ecological urbanism in the Eastern Amazon"

In the same article, on page 96 :

Where it reads:

"Western Amazonian"

It should read:

"Eastern Amazonian"

In the same article, on page 97 :

Where it reads:

"Western Amazon frontier"

It should read:

"Eastern Amazon frontier"

In the same article, on page 99:

Where it reads:

"Reation and dissolution of the city-nature dichotomy in the history of the city"

It should read:

"Creation and dissolution of the city-nature dichotomy in the history of the city".

In the same article, on page 102:

Where it reads:

"The contemporary city form: the new protagonist of open spaces"

It should read:

"The contemporary city form: the new protagonism of open spaces"

In the same article, on page 105:

Where it reads:

"ATTRACTIVELY"

It should read:

"ATTRACTIVENESS"

In the same article, on page 105:

Where it reads:

"Original compilation from sources cited in the text. Authors (2015). Cartographic base: Wikimapia (2015)"

It should read:

"Original compilation from sources cited in the text". 